Original Research Paper

\title{
Trade Linkages between Malaysia and the OIC Member Countries: Empirical Evidence Based on Gravity Model
}

\author{
${ }^{1}$ Irwan Shah Zainal Abidin, ${ }^{2}$ Mohd Dan Jantan, ${ }^{3}$ Nurulhuda Mohd Satar and ${ }^{4}$ Muhammad Haseeb \\ ${ }^{1,4}$ College of Business, Universiti Utara Malaysia, 06010 Sintok Kedah, Malaysia \\ ${ }^{2}$ College of Business, Northern University of Malaysia, 06010 Sintok, Kedah, Malaysia \\ ${ }^{3}$ Faculty of Economics and Administration, University of Malaya 50603 Kuala Lumpur, Malaysia
}

Article history

Received: 17-10-2014

Revised: $13-12-2014$

Accepted: 20-12-2014

Corresponding Author: Muhammad Haseeb

College of Business, Universiti

Utara Malaysia, 06010 Sintok

Kedah, Malaysia

Email: scholar_economist@yahoo.co.uk

\begin{abstract}
This study examines trade relations between Malaysia and 55 of the Organization of Islamic Cooperation (OIC) member countries for the period of 1995 to 2012. Applying the Trade Gravity Model (TGM), the study will isolate factors that determine Malaysia-OIC trade measured by Malaysian exports to OIC member countries. Since the series are integrated of order 1 and appear to be cointegrated, we utilize the Fully Modified OLS (FMOLS) to estimate the determinants of trade between Malaysia and OIC countries. The FMOLS estimation reported that per capita GDP, Foreign Direct Investement (FDI) differential and real exchange rate of OIC member countries are supporting the expansion of the exports whereas any increase in trade per GDP ratio, corruption and real exchange rate of Malaysia creates additional impediments to the trade relation. The findings suggest that economic strengthening as the basis for increase in trade between Malaysia and OIC members. Investment appears to be complementary to the trading relations in the Malaysia-OIC case. The social capital also plays role in supporting the traade.
\end{abstract}

Keywords: International Trade, Gravity Model, Panel Data, Malaysia, OIC JEL Classification: F13, F14

\section{Introduction}

International trade has always been playing a crucial role in the process of growth and development in Malaysia, especially in transforming the economy from a low income to upper-middle income category. Traditionally, Malaysia's major trading partners were the United States of America, the European Union (EU) and Japan. But this trend has been shifted somewhat primarily due to the 2008/09 world economic and financial crises. In 2009 for example, Malaysia's major exporting and importing nations have tilted more towards other new markets and non-traditional countries such as China (MMITI, 2009). In response to the crises, the Malaysian government, under the New Economic Model (NEM), has embarked on a new strategy to shift its trade dependency on the traditional markets and exploring new markets for exports and imports. Under NEM, one of the markets being targeted is the Middle Eastern countries.

The prospects and opportunities in forging a closer and deeper regional economic co-operation under OIC, particularly with the rich Arab countries are yet to be fully tapped especially through the means of trade (Khadijah, 2004). Furthermore, the 2008/09 world economic and financial crisis and in the aftermath of the September 11 terrorist attack have made the trade relationship between Malaysia and the OIC countries becoming more relevant than ever especially in the sphere of economic cooperation. It is therefore crucial to examine and analyze the on-going Malaysia-OIC trade relationship in this context.

Over the recent years, Malaysia-OIC trade relationship is relatively small as compared to Malaysia's trade with the rest of the world although it has shown an increasing pattern.

Figure 1 summarizes the overall picture of Malaysia-OIC trade relations. Malaysia's total trade has been increasing since 1994 to 2012 and the pattern of trade suggests that the major contributor of the trade increment is non-OIC, traditional trading partners of Malaysia. The percentage of trade between Malaysia and its OIC counterparts grows sluggishly over the observed decade. In 1994 OIC members account for merely $3.7 \%$ of Malaysia's total trade and share increase to $7.9 \%$ in 2012 . Considering that the OIC countries have more than $60 \%$ of vital resources and with 1.3 billion or one-sixth of the world's population, this general picture of the state of OIC trade performance can be deemed as weak. 


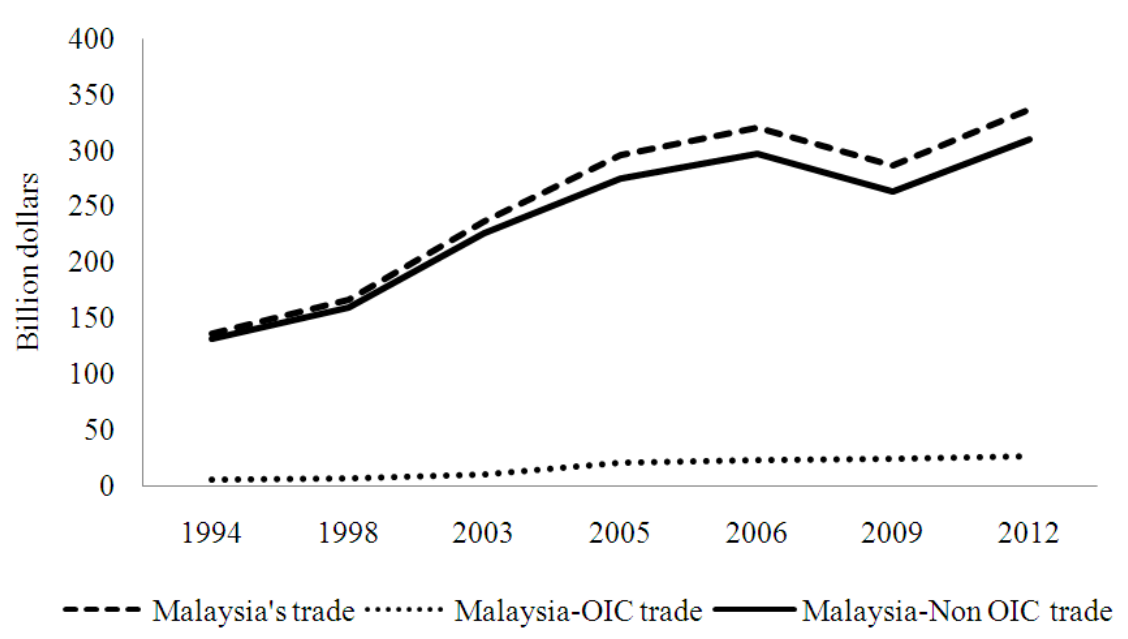

Fig. 1. Malaysia-OIC Trade for the Year 1994, 1998, 2003, 2005, 2006, 2009 and 2012 Source: http://www.carsicm.ir/icmroot/public/Statistics/OIC-View.htm

Although there are many factors responsible for the weaknesses of this trade relation, the leaders and the people of the OIC countries believe that there are many fields and opportunities for growth of mutual trade relations.

Table 1 indicates that among Malaysia's major trading partners in the OIC are Indonesia, Saudi Arabia, U.A.E., Pakistan, Turkey and Brunei. Overall, the trade performance in terms of value between Malaysia and the OIC member countries has shown an increasing trend. Malaysia's trade with Indonesia for example has increased substantially from USD658.3 million in 1990 to USD19042.42 million in 2009. This sharp increase in trade volume between these two countries from 1990 to 2012 is due to factors such as common language, cultural affinity, historical backgrounds and similar borders. Nonetheless, apart from being partners under the OIC umbrella, the trade between Malaysia and Indonesia has long been developed.

This study aims at examining the factors driving the trade between Malaysia and OIC countries utilizing the Fully Modified OLS estimation approach considering the non stationarity and existence of long run relationship between the variables under consideration. The paper starts with background of Malaysia-OIC trade relations then presents previous works that have examined the determinants of bilateral trade. Section 3 explains the methodology employed to examine the determinants of trade between Malaysia and OIC member countries. In section 4, the results are presented and discussed. Finally conclusions are made based on the findings.

\section{Gravity Approach and Determinants of Trade}

The gravity model was first applied to international trade studies by (Tinbergern, 1962; Poyhonen, 1963) to analyze the patterns of bilateral trade flows among the
European countries. The model is based on the analogy of Newton's law of gravity which states that the bilateral trade flows between two countries is proportional to its Gross Domestic Product (GDP) as a proxy of size and diminishes with distance, other things being equal (Krugman and Obstfeld, 2009) Later, the model has been augmented to take into account other factors in explaining trade flows among countries. Bergstrand (1985) for instance includes price and exchange rate variable to his gravity specification. Subsequently, he introduces the per capita income, Wholesale Price Index (WPI) and dummy variables for trade agreement to explain the shape of international trade to the model (Bergstrand, 1989). Dummy variables for common border and language was first introduce to the model by (Frankel et al., 1995) with the argument that trade is easier between two neighboring countries and countries that share similar language. Political and institutional variables are found to be one the key determinants influencing trade relations (Summary, 1989; Dollar and Kraay, 2002; Levchenko, 2004; Anderson and Marcoullier, 2002). They found positive relationship between bilateral trade flows and the political and institutional qualities.

Endoh (1999) employed population variable in the model, which has a negative effects on trade flows. Frankel et al. (1995; Elliott and Ikemoto, 2004) introduced per capita income as a proxy to the level of development in explaining international trade. Filippini and Molini (2003) pointed out that there are two aspects worth mentioning when using gravity model, that is, the concepts of distance and mass ought to be reinterpreted according to the social and economic phenomenon under scrutiny and the multiplicative formulation of the law was generally kept even if an additive one might have seemed to be as good as the other. 
Table 1. The OIC member countries trade with Malaysia, selected years and countries (USD in Million)

\begin{tabular}{|c|c|c|c|c|c|c|c|c|c|}
\hline Year/Country & 1990 & 1994 & 1997 & 1999 & 2001 & 2003 & 2006 & 2009 & 2012 \\
\hline Indonesia & 658.30 & 1656.62 & 2688.96 & 2987.91 & 3804.49 & 5068.16 & 9025.81 & 11478.91 & 19042.42 \\
\hline Saudi Arabia & 297.22 & 491.30 & 659.39 & 588.07 & 977.73 & 991.84 & 2860.09 & 1920.25 & 3682.13 \\
\hline U.A.E. & 211.59 & 527.90 & 765.96 & 836.95 & 997.29 & 1415.32 & 3238.67 & 4590.91 & 8040.64 \\
\hline Pakistan & 274.20 & 726.58 & 665.30 & 569.52 & 443.15 & 715.95 & 902.22 & 1782.24 & 2105.77 \\
\hline Turkey & 101.90 & 338.06 & 461.25 & 332.96 & 409.91 & 361.63 & 702.62 & 590.52 & 1024.58 \\
\hline Brunei & 86.16 & 293.54 & 297.80 & 224.88 & 278.01 & 349.46 & 421.09 & 510.33 & 746.36 \\
\hline Iran & 91.00 & 104.31 & 139.11 & 137.08 & 327.48 & 428.37 & 1022.60 & 1010.00 & 1482.59 \\
\hline Qatar & 21.16 & 20.21 & 36.81 & 32.27 & 77.12 & 53.43 & 266.12 & 881.00 & 1581.91 \\
\hline Bangladesh & 49.43 & 80.63 & 196.54 & 140.74 & 186.62 & 335.37 & 445.03 & 830.62 & 1584.53 \\
\hline Egypt & 132.15 & 195.78 & 229.78 & 323.21 & 219.77 & 477.92 & 390.94 & 844.87 & 1255.96 \\
\hline Jordan & 112.33 & 117.25 & 168.71 & 104.26 & 91.48 & 108.91 & 208.48 & 175.28 & 242.10 \\
\hline Yemen & 50.99 & 49.23 & 56.52 & 86.73 & 346.07 & 316.74 & 314.47 & 277.52 & 211.00 \\
\hline
\end{tabular}

Source: Direction of trade statistics, international monetary fund

Asmak and Abu-Hussin (2009) analyzed Malaysia's trade relations with the Gulf Cooperation Council (GCC) countries which consist of the United Arab Emirates (UAE), Bahrain, Saudi Arabia, Oman, Qatar and Kuwait. Using trade intensity index, they showed that Malaysia's trade with the individual GCC country and with GCC as a group were very low during the 1990-2007 period of study. They suggested that to improve Malaysia-GCC trade relations in the future, the countries need to expedite the Free Trade Agreement (FTA) initiative and focusing on niche areas which they have comparative advantage at such as Halal Food services, Islamic Banking and Finance services, tourism sector, Bio-fuel industries, constructions, education sector and petrochemical industries.

Whereas, Evelyn et al. (2011) find that based on their Gravity Model estimation, culture and religion are insignificant in enhancing bilateral trade between Malaysia and the GCC countries. By using a qualitative method of semi-structured interviews, Abu-Hussin (2010) has arrived into the same conclusion that religious affinity does not help in terms promoting business relations of Malaysia-GCC countries. He also explored the trade relationship between Malaysia and the Gulf Cooperation Council (GCC) countries by employing the Revealed Comparative Advantage (RCA) and the trade intensity index. Through these analyses, he discovered that the trade linkages are still insignificant relative to Malaysia's traditional trading partners (Ismail and Panni, 2008). on the other hand, examined the pattern of trade between Malaysia and eighty trading partners, where twenty of which are OIC members. In his research, he found that Malaysia trade with countries which have similar in terms of size but different in terms of factor endowment.

Balassa (1961) showed that as the economic integration increases, trade barriers or forms of protectionism, such as tariffs, non-tariff restrictions, import quotas, government regulations, etc., would decrease. Studies specifically addressed on the issue of the establishment of the Islamic Common Market (ICM) as a long term goal for OIC are still scarce (Amin and Hamid, 2009). But there are some studies which supported the establishment of the ICM. Shalaby (1988; Anjum, 1996; Ariff, 1998; Ahmed and Ugurel, 1998; Dabour, 2004; Amin and Hamid, 2009) are among them.

Hassan (1998) proposed that the establishment of the Islamic Common Market (ICM) is a step in the right direction and the way forward for the OIC member countries to enhance their trade relationship in the long term. Amin and Hamid (2009) showed that the OIC is now heading in the right direction as far as the establishment of the ICM is concerned. But they warned that the major impediment for the materialization of the ICM was a lack of political commitment among the member countries.

Using dynamic panel estimation, Mawar Murni and Mohd Adib (2009) found the main determinants of bilateral trade between Malaysia and its major trading partner are GDP of both countries, FDI, exchange rates, distance and border. They estimate the gravity model for Malaysia's exports with 96 trade partners including 36 OIC member countries. The augmented gravity estimation includes a dummy on OIC and non-OIC and found that the coefficient to be negative but insignificant suggesting that there is no difference between Malaysian exports to OIC and non OIC member countries. They conclude that there are rooms for improvement of trade between Malaysia and OIC.

\section{Model Specification and Data}

\section{The Bilateral Trade Model}

The gravity model of trade depends on the balance of the forces in between the trading economies. Its stochastic specification is mentioned as follow:

$$
\begin{aligned}
& \ln \left(\operatorname{Trade}_{i j t}\right)=\alpha_{0}+\beta_{1} \ln \left(P C G D P_{i t}\right)+\beta_{2} \ln \left(P C G D P_{j t}\right) \\
& +\beta_{3} \ln \left(D I S T_{i j}\right) \beta_{4} \ln \left(F D I_{i t}\right)+\beta_{5} \ln \left(F D I_{j t}\right)+\beta_{6} \ln \left(F D I_{i j t}\right) \\
& +\beta_{7} \ln \left(T R / G D P_{i t}\right)+\beta_{8} \ln \left(T R / G D P_{j t}\right) \\
& +\beta_{9} \ln \left(I N S_{i t}\right)+\beta_{10} \ln \left(I N S_{i j}\right)+\beta_{11} \ln \left(E R_{i t}\right)+\beta_{12} \ln \left(E R_{j t}\right)+\varepsilon_{i j t}
\end{aligned}
$$




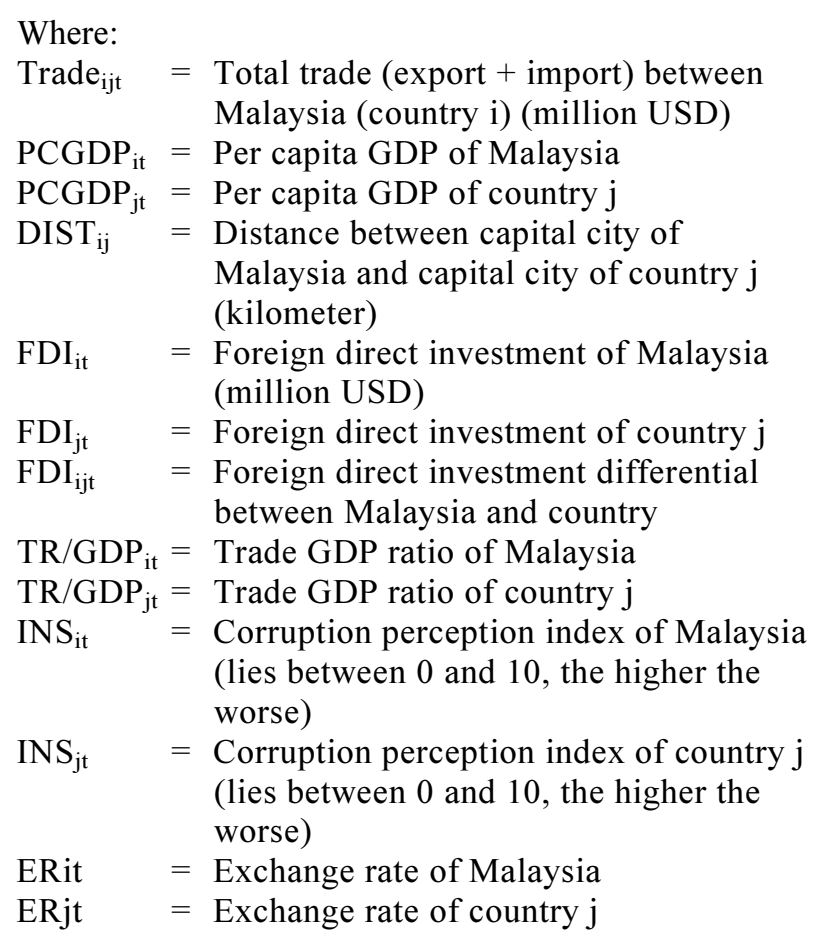

\section{Method of Estimation}

Building on the econometric estimation of gravity model, there are about 17 observations for each country from year 1995 to 2012, because of these long time series component these variables are expected to become function of their past. Considering variables becoming function of its past values it will consequently make residuals function of its past too, which by assumption of Ordinary Least Square will cause regression result to be invalid. Therefore we start by examining whether the series follow random walk process. We use (Im et al., 2003; Maddala and $\mathrm{Wu}, 1999$ ) to test for existence of unit root. Next, cointegration test is applied to the series to examine whether they have a long run relationship following (Kao, 1999).

\section{Long Run Model}

If the variables are proved to be cointegrated, Pedroni (2001) suggest the estimation to be done using Fully Modified OLS to estimate the long run coefficients. Following are the mathematical illustration of this FMOLS model. This model is made to estimate panel cointegrated coefficients Equation 1-3:

$$
\begin{aligned}
& y_{i t}=\alpha_{i}+\delta_{i}^{\prime} d_{i t}+x_{i t}^{\prime} \beta+u_{i t} \\
& y_{i t}^{+}=y_{i t}-\sigma_{i,}^{\prime} \sum_{i,}^{-1} x_{i t} \\
& \hat{\beta}_{F M O L S}=\left[\sum_{i=1}^{N} \sum_{t=1}^{T} x_{i t} x_{i t}^{\prime}\right]^{-1}\left[\sum_{i=1}^{N} \sum_{t=1}^{T}\left(x_{i t} y_{i t}^{+}-\lambda_{i, t}\right)\right]
\end{aligned}
$$

\section{Short Run Model}

The residuals of the FMOLS model will be stored as ECM variable, which will be tested for presence of unit root. If the selected variables are found to be cointegrated then ECM variable will be expected to have no unit root (stationary) which is also confirmed via KAO cointegration test Equation 4:

$\Delta y_{i t}=\alpha+\Delta x_{i t}^{\prime} \beta^{\prime \prime}-\gamma E C M_{t-1}+u_{i t}$

In this short run model if coefficient of lagged ECM is $-1<\gamma<0$ and significant then it will confirm that any disequilibrium in the long run cointegrating equilibrium model estimated by FMOLS is adjusted back towards the equilibrium through change in the dependent variable in the model which is TRADE $\mathrm{i}_{\mathrm{ij}}$. Here $\beta$ " will provide the short run effects of all the included independent variable in the dependent variable.

\section{Data}

We use compile data of 55 OIC member countries for the period of 1995 to 2012. Data on Gross Domestic Product $(G D P), G D P$ per capita, Foreign Direct Investments (FDIs), real exchange rates, total exports, total imports, obtained from the World Development Indicators (WDI) database of the World Bank and also from IMF's International Financial Statistics (IFS). Data on Malaysia's exports (country $i$ export) to all other countries (country $j$ 's), Malaysia's imports (country $i$ imports) from all other countries (country $j$ 's) are obtained from IMF's Direction of trade statistics, CD-ROM database. All monetary data are adjusted to real values using deflator with 2005 as the base year obtained from the IFS.

Data on the distance (in kilometer) between Kuala Lumpur (capital of Malaysia) and other capital cities of country $j$ are obtained from an Indonesian website: www.indo.com/distance. For the measurement of the level of institutional quality, that is measured by the corruption index is obtained from the Corruption Perceptions Index (CPI) from Transparency International (TI) and retrieved from TI database at www.transparency.org/cpi. The index scale from 1 to 10 , the lower the scale represents better institutional condition with respect to corruption.

\section{Empirical Results}

In this section all the variables are tested for the presence of unit root using four tests (LLC, IPS, Fisher ADF and Fisher PPP) on level and first difference specification of the variable. All variables are found to be integrated of order 1, stationary at first difference.

Results from above Table 2 shows that almost all the variables are clearly I(1) with few like $\mathrm{LNFDI}_{\mathrm{i}}, \mathrm{LNFDI}_{\mathrm{j}}$,

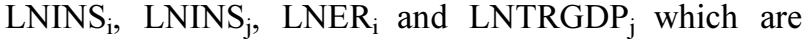


decided to be I(1) on the basis of majority in four unit root tests. This confirms that standard panel data models like Pooled OLS, Fixed effect and Random effect models are inappropriate. Hence this study will proceed towards appropriate model which can incorporate I(1) variables. The set of $\mathrm{I}(1)$ variable will only provide meaningful outcome if they are cointegrated. The ADF Kao cointegration test on the residuals show significant evidence (t-stats -3.09) for the presence of cointegration among the variables in gravity model, this suggest that gravity type of trade relation model exists between Malaysia and selected OIC countries.

The presence of cointegration using KAO test provides evidence that the estimation results from FMOLS model will not be spurious and this FMOLS model can be used to estimate the long run coefficients of the model. Since Gravity model is providing us a hypothetical framework of how trade behaves hence if this model is valid than it should form equilibrium model which requires the residuals (i.e., disequilibrium) to be stationary with zero mean and constant variance (mathematically zero).

Table 3 below provides another confirmation regarding presence of cointegration as the residuals generated from the FMOLS are proved to be stationary using LLC, Fisher ADF and Fisher PP test.

Table 4 represent the short run component of Gravity model, here $\operatorname{ECM}(-1)$ is an important indicator for the performance of the model it should be between -1 and 0 and significant in order to show convergence towards equilibrium in the model. Here the coefficient of ECM(-1) is -0.38 and it is significant at $5 \%$ which means that if there is any disequilibrium (deviation in trade which is not explained by the model) then there will be $38 \%$ adjustment toward equilibrium each time period (adjustment is usually performed using the dependent variable).

Table 5 reports the results from FMOLS estimation. R square statistic represent that $93 \%$ of the variation in the trade between Malaysia and OIC countries is explained by the independent variables selected as per gravity model of international trade which is a significant portion of trade. The results presented in Table 3 shows that LNPCGDP LNPCGDP $_{j}, L_{\text {LNFDI }}$ ij and LNER $_{\mathrm{jt}}$ are significantly and positively effecting in expansion of trade between Malaysia and OIC countries where as indicators like LNTRGDP LNINS $_{i}$ and LNER $_{i}$ are significantly and negatively effecting in contraction of trade between Malaysia and OIC countries. (Compare to previous studies' findings).

Table 2. Unit root test results

\begin{tabular}{|c|c|c|c|c|c|}
\hline Panel A: Levin et al. (2002) Test & Level & First difference & Panel B: Im et al. (2003) W-Test & Level & First difference \\
\hline$\overline{\text { LNPCGDP }}_{\text {it }}$ & 1.000 & $0.000^{*}$ & LNPCGDP $_{\text {it }}$ & 1.000 & $0.000 *$ \\
\hline LNPCGDP $_{j t}$ & 1.000 & $0.000 *$ & LNPCGDP $_{j t}$ & 1.000 & $0.000 *$ \\
\hline LNER $_{\text {it }}$ & 1.000 & $0.000^{*}$ & LNER $_{\text {it }}$ & $0.000 *$ & - \\
\hline LNERjt & 0.902 & $0.000 *$ & LNERjt & 0.981 & $0.000 *$ \\
\hline LNFDI $_{\text {it }}$ & 1.000 & $0.000 *$ & $\mathrm{LNFDI}_{\mathrm{it}}$ & $0.03 *$ & - \\
\hline $\mathrm{LNFDI}_{\mathrm{jt}}$ & $0.009^{*}$ & - & $\mathrm{LNFDI}_{\mathrm{jt}}$ & 0.745 & $0.000 *$ \\
\hline LNFDI $_{i j t}$ & 1.000 & $0.000 *$ & LNFDI $_{\mathrm{ijt}}$ & 1.000 & $0.000 *$ \\
\hline LNTRGDP $_{\text {it }}$ & 1.000 & $0.000 *$ & LNTRGDP $_{\text {it }}$ & 1.000 & $0.000 *$ \\
\hline LNTRGDP $_{\mathrm{jt}}$ & $0.02 *$ & - & LNTRGDP $_{\mathrm{jt}}$ & 0.413 & $0.000^{*}$ \\
\hline LNTRADE $_{\mathrm{ij}}$ & 0.4046 & $0.000 *$ & LNTRADE $_{\mathrm{ij}}$ & 1.000 & $0.000^{*}$ \\
\hline Panel C: ADF fisher chi square & Level & First difference & Panel D: PP fisher chi square & Level & First difference \\
\hline LNPCGDP $_{\text {it }}$ & 1.000 & $0.000^{*}$ & LNPCGDP $_{i t}$ & 1.000 & $0.000^{*}$ \\
\hline LNPCGDP $_{\mathrm{jt}}$ & 1.000 & $0.000 *$ & LNPCGDP $_{\mathrm{jt}}$ & 1.000 & $0.000 *$ \\
\hline LNER $_{\text {it }}$ & 1.000 & $0.000 *$ & LNER $_{\text {it }}$ & 0.234 & $0.000 *$ \\
\hline LNERjt & 0.943 & $0.000 *$ & LNERjt & 0.968 & $0.000 *$ \\
\hline LNFDI $_{\text {it }}$ & 0.984 & $0.000 *$ & LNFDI $_{\text {it }}$ & 0.000 & - \\
\hline $\mathrm{LNFDI}_{\mathrm{jt}}$ & 0.951 & $0.000 *$ & $\mathrm{LNFDI}_{\mathrm{jt}}$ & 0.102 & $0.000^{*}$ \\
\hline LNFDI $_{\mathrm{ijt}}$ & 1.000 & $0.000 *$ & LNFDI $_{\mathrm{ijt}}$ & 1.000 & $0.000 *$ \\
\hline LNTRGDP $_{\text {it }}$ & 1.000 & $0.000 *$ & LNTRGDP $_{\text {it }}$ & 1.000 & $0.000^{*}$ \\
\hline LNTRGDP $_{\mathrm{jt}}$ & 0.400 & $0.000 *$ & LNTRGDP $_{\mathrm{jt}}$ & 1.000 & $0.000^{*}$ \\
\hline LNTRADE $_{\mathrm{ij}}$ & 0.9998 & $0.000 *$ & LNTRADE $_{\mathrm{ij}}$ & 0.9803 & $0.000 *$ \\
\hline
\end{tabular}

Note:*denoted statistically significant at 5\% level

Table 3. Results of ECM Residual

\begin{tabular}{|c|c|c|c|c|}
\hline \multirow[b]{2}{*}{ Test } & \multicolumn{2}{|l|}{ Level } & \multicolumn{2}{|c|}{ First difference } \\
\hline & t-statistics & p-values & t-statistic & p-value \\
\hline Levin et al. (2002) Test & -6.56350 & 0.000 & -12.0948 & $0.000^{*}$ \\
\hline ADF Fisher Chi Square & 96.9407 & 0.000 & 162.228 & $0.000^{*}$ \\
\hline PP Fisher Chi Square & 95.9899 & 0.000 & 183.159 & $0.000^{*}$ \\
\hline
\end{tabular}

Note:*denoted statistically significant at 5\% level 
Table 4. Results of Panel ECM (dependent variable $\triangle$ LNEXPORT $_{\text {ij }}$ )

\begin{tabular}{|c|c|c|c|c|}
\hline Variables & Coefficient & Std. Error & $t$-value & $P$-value \\
\hline$\overline{\text { DLNTRADEGDP }}_{\mathrm{i}}$ & -0.11 & 1.20 & -0.090 & 0.9280 \\
\hline DLNTRADEGDP $_{i}$ & 3.27 & 2.53 & 1.290 & 0.2076 \\
\hline DLNPCGDP $_{j}$ & 1.20 & 1.43 & 0.840 & 0.4070 \\
\hline DLNPCGDP $_{i}$ & 2.14 & 1.66 & 1.280 & 0.2109 \\
\hline DLNINS $_{\mathrm{j}}$ & 0.27 & 0.43 & 0.630 & 0.5356 \\
\hline DLNINS $_{\mathrm{i}}$ & 0.05 & 1.44 & 0.040 & 0.9701 \\
\hline DLNFDI $_{j}$ & -0.04 & 0.11 & -0.400 & 0.6952 \\
\hline DLNFDI $_{i j}$ & 0.05 & 0.34 & 0.140 & 0.8857 \\
\hline DLNFDI $_{\mathrm{i}}$ & -0.36 & 0.52 & -0.690 & 0.4947 \\
\hline DLNER $_{j}$ & 0.85 & 1.96 & 0.440 & 0.6660 \\
\hline DLNER $_{i}$ & -0.01 & 3.34 & -0.003 & 0.9975 \\
\hline $\operatorname{ECM}(-1)$ & -0.38 & 0.16 & -2.280 & 0.0311 \\
\hline $\mathrm{C}$ & 0.01 & 0.14 & 0.090 & 0.9265 \\
\hline $\mathrm{R}$ square & & & 0.410 & \\
\hline DW test & & & 2.510 & \\
\hline
\end{tabular}

Table 5. Fully Modified OLS estimation results (dependent variable: LNTRADE ${ }_{\mathrm{ii}}$ )

\begin{tabular}{|c|c|c|c|c|}
\hline Variables & Coefficient & Std. Error & $t$-value & $P$-value \\
\hline LNPCGDP $_{\text {it }}$ & 1.27 & 0.14 & 9.07 & $0.0000 *$ \\
\hline LNPCGDP $_{\mathrm{jt}}$ & 0.41 & 0.09 & 4.25 & $0.0000 *$ \\
\hline $\mathrm{LNFDI}_{\text {it }}$ & 0.08 & 0.11 & 0.79 & 0.4309 \\
\hline $\mathrm{LNFDI}_{\mathrm{jt}}$ & 0.06 & 0.11 & 0.58 & 0.5600 \\
\hline LNFDI $_{i j t}$ & 1.12 & 0.20 & 3.34 & $0.0002 *$ \\
\hline LNTRGDP $_{\text {it }}$ & -0.99 & 0.13 & -7.50 & $0.0000^{*}$ \\
\hline LNTRGDP $_{\mathrm{jt}}$ & 0.10 & 0.07 & 1.49 & 0.1393 \\
\hline LNINS $_{\text {it }}$ & -0.55 & 0.15 & -3.55 & $0.0005^{*}$ \\
\hline LNINS $_{\mathrm{jt}}$ & -0.01 & 0.12 & -0.06 & 0.9482 \\
\hline $\mathrm{LNER}_{\mathrm{it}}$ & -1.51 & 0.06 & -24.58 & $0.0000 *$ \\
\hline $\mathrm{LNER}_{\mathrm{jt}}$ & 0.60 & 0.06 & 10.00 & $0.0000 *$ \\
\hline LNDIST $_{\text {ijt }}$ & 6.00 & 3.53 & 1.70 & $0.0170 *$ \\
\hline R Square & & & 0.93 & \\
\hline
\end{tabular}

Note:*denoted statistically significant at 5\% level

\section{Concluding Remarks}

The aim of this study is to investigate empirically on bilateral trade relations between Malaysia and the OIC countries. Estimation of the Malaysia-OIC gravity model of trade revealed that per capita GDP of Malaysia, per capita GDP of OIC countries, corruption in OIC countries, foreign direct investment of Malaysia-OIC countries and real exchange rate of OIC countries significantly and positively effect on Malaysia-OIC trade. While, trade per capita GDP, corruption and real exchange rate of Malaysia shows significant negative effect on Malaysia-OIC trade. We also found that distance does not significantly explain the trade volume between Malaysia and OIC member countries. The results suggest the importance of institutional improvement in enhancing Malaysia-OIC trade.

These finding and results are important especially for policy makers in crafting policies to improve MalaysiaOIC trade relationship in the future. In line with the empirical findings, it is crucial for Malaysian government to focus on accelerating the efforts to establish the Islamic Common Market (ICM), liberalizing the economy, further improving the strategic sectors such as the Islamic Banking and Finance and intensify endeavors in curbing corrupt practice.

\section{Acknowledgement}

The researchers thank the Department of Higher Education (formally Ministry of Higher Education) for the research grant. This research is funded under the Research Acculturation Grant Scheme. The first version of this study was presented at the Eurasia Business Research Conference in Istanbul Turkey. Authors declare no conflict of interest.

\section{Author's Contributions}

All authors equally contributed in this work.

\section{Ethics}

This article is original and contains unpublished material. The corresponding author confirms that all of the other authors have read and approved the manuscript and no ethical issues involved.

\section{References}

Abu-Hussin, M.F., 2010. Exploring international trade between Malaysia and GCC countries: Empirical analysis on trends, developments and challenges. $\mathrm{PhD}$. Thesis, Durham University, United Kingdom. 
Ahmed, Z. and I. Ugurel, 1998. The Islamic capital market: Is it economically and politically justifiable?. Humanomics, 14: 79-117. DOI: $10.1108 / \mathrm{eb} 018818$

Amin, R.M. and Z. Hamid, 2009. Towards an Islamic common market: Are OIC countries heading the right direction?. IIUM J. Econ. Manage., 17: 133-176.

Anderson, J.E. and D. Marcouiller, 2002. Insecurity and the pattern of trade: An empirical investigation. Rev. Econom Statist., 84: 342-352. DOI: $10.1162 / 003465302317411587$

Anjum, M.I., 1996. The challenges of establishing an Islamic common market: Ideals, realities and tasks ahead. Proceeding of the presented at the 2 nd International Conference on Islamic Political Economy, Dec. 10-11, Penang, Malaysia.

Ariff, M., 1998. Proliferation of regional groupings: Policy options for the OIC. J. Econ. Cooperat. Among Islamic Countr., 19: 15-29.

Asmak, A.R. and M.F. Abu-Hussin, 2009. GCC economic integration challenge and opportunity for Malaysian economy. J. Int. Social Res., 2: 43-55.

Balassa, B., 1961. The Theory of Economic Integration. 1st Edn., Allen and Unwin, London.

Bergstrand, J.H., 1985. The gravity equation in international trade: Some microeconomic foundations and empirical evidence. Rev. Econom. Statist., 67: 474-481. DOI: 10.2307/1925976

Bergstrand, J.H., 1989. The generalised gravity equation, monopolistic competition and the factor proportion theory in international trade. Rev. Econ. Statist., 71: 143-153. DOI: $10.2307 / 1928061$

Dabour, N.M., 2004. Implications of establishing an Islamic common market: Gradual integration and possible consequences. J. Econ. Cooperat., 25: 71-98.

Dollar, D. and A. Kraay, 2002. Institutions, trade and growth. J. Monetary Econom, 50: 133-162. DOI: 10.1016/S0304-3932(02)00206-4

Elliott, R.J. and K. Ikemoto, 2004. AFTA and the Asian Crisis: Help or hindrance to ASEAN intra-regional trade?. Asian Econ. J., 18: 1-23. DOI: $10.1111 /$ j.1467-8381.2004.00179.x

Endoh, M., 1999. Trade creation and trade diversion in the EEC, the LAFTA and the CMEA: 1960-1994. Applied Econom., 31: 207-216. DOI: $10.1080 / 000368499324435$

Evelyn, S., Z. Ahmad and S. Thirunaukarasu, 2011. Leveraging trade opportunities with nontraditional partners: The Malaysia-GCC perspective. Proceedings of the International Conference on International Trade and Investment: Globalisation at CrossroadsImplications for the Developing World, Dec. 2021, Le Meridien Hotel, Mauritius, pp: 97-122. DOI: $10.1080 / 09512748.2013 .848377$
Filippini, C. and V. Molini, 2003. The determinants of east Asian trade flows: A gravity equation approach. J. Asian Econom., 14: 695-711. DOI: $10.1016 /$ j.asieco.2003.10.001

Frankel, J.A., E. Stein and S. Wei, 1995. Trading blocs and the Americas: The natural, the unnatural and the super-natural. J. Develop. Econom., 47: 61-95. DOI: 10.1016/0304-3878(95)00005-4

Hassan, M.K., 1998. An empirical investigation of economic cooperation among the OIC member countries. Econom. Res. Forum.

Im, K.S., M.H. Pesaran and Y. Shin, 2003. Testing for unit roots in heterogeneous panels. J. Econometr., 115: 53-74.

Ismail, H.B. and M. Panni, 2008. Consumer perceptions on the consumerism issues and its influence on their purchasing behavior: A view from Malaysian food industry. J. Legal, Ethical Regulatory, 11: 43-64.

Kao, C., 1999. Spurious regression and residual-based tests for cointegration in panel data. J. Econometr., 90: 1-44. DOI: 10.1016/S0304-4076(98)00023-2

Khadijah, K., 2004. Malaysia's growing economic relations with the Muslim world. Kyoto Rev. Southeast Asia, 20: 18-25.

Krugman, P.R. and M. Obstfeld, 2009. International Economics: Policy and Theory. Canada Pearson (Addison-Wesley).

Levchenko, A.A., 2004. Institutional quality and international trade. International Monetary Fund, ISBN-10: 1451920164, pp: 45.

Levin, A., C. Lin and C.S.J. Chu, 2002. nUnit root test in panel data: Asymptotic and finite sample propertieso. J. Econometr., 108: 24-24.

Maddala, G.S. and S. Wu, 1999. A comparative study of unit root tests with panel data and a new simple test. Oxford Bulletin Econom. Statist., 61: 631-652.

Mawar Murni, Y. and I. Mohd Adib, 2009. MalaysiaOIC trade: A gravity approach.

MMITI, 2009. MITI Annual Report 2008, Kuala Lumpur, Malaysia. Malaysian Ministry of International Trade and Industry

Pedroni, P., 2001. Fully modified OLS for heterogeneous cointegrated panels. Adv. Econometr., 15: 93-130.

Poyhonen, P., 1963. A tentative model for the volume of trade between countries. Welwirtschaftliches Archiv, 90: 93-99.

Shalaby, I., 1988. The Islamic common market. J. Islamic Bank. Finance, 24: 53-68.

Summary, R., 1989. A political-economic model of U.S. bilateral trade. Rev. Econom. Statist., 71: 179-182.

Tinbergern, J., 1962. Shaping the world economy: Suggestions for an international economic policy. J. Farm Econom., 46: 271-283. 